\title{
Effect of National Brand Equity on Export
}

\author{
Nasser Fegh-hi Farahmand, PhD. \\ Department of Industrial Management, Tabriz \\ Branch, Islamic Azad University, Tabriz, Iran
}

\author{
Rosita Dabaghafrouz \\ Graduated of Industrial Management, Tabriz \\ Branch, Islamic Azad University, Tabriz, Iran
}

\begin{abstract}
The Purpose of this study is evaluating the effect of sanctions and custom duties and other limitations of national Iran's brand equity on exports. Rising of global competitions and necessity of attentions on issues of international marketing, led to conduction of many researches on these fields. Main purpose of this study is assessing the role of origin Country as national brand on the leather industry export. The data of this research collected through survey Questionnaire .Questionnaire sent by e-mail for Leather customers in abroad. The results showed that all three factors of brand equity in the statistical community have no effect on exports. Other factors Such as customs duties and sanctions are also barriers to impact of brand equity. Manufacturers avoided releasing Emails of foreign customer (importers of leather, Iran). The questionnaire placed at their disposal, so they personally would email it to their customers. This study showed that the sanctions, political issues, economic banking laws in each country, will affect brand equity seriously. Practical implications: with special attention to the manufacturer's brand equity and its dimensions, we can increase export.
\end{abstract}

\section{Keywords}

National brand equity, Iran's brand perceived quality, Iran's brand performance, exports

\section{INTRODUCTION}

In recent years, different industries in all over the world have developed in developing countries. This trend accompanied by increasing interest in international competition, the origin country has considered as part of International Marketing. This case been led to much research in this field and effects of origin country. However, these companies faced with myriad challenges. One of these challenges is negative perceptions of the origin country and its effects on Brand. Another challenge is the sanctions against origin country and difficult laws and barriers of origin country for customers. Existing research about the country of origin shows the country of origin is a critical factor for successful international marketing strategy. Because Mentality country of origin formed in the minds of consumers is not easy to change and are effects long-term.

\section{BRAND}

Various studies conducted to analyze the effect of a brand's origin country about the perceptions it forms among consumers. Typically, country of origin serves as a cognitive cue that provides a consumer a method of evaluating certain products based on his/her beliefs about the country from which it originates (Verlegh \& Steenkamp, 1999).By creating a symbolic and emotional attachment with consumers, country of origin has become a primary method of product evaluation. Influenced by country stereotypes, consumers assess an organization's product based on its "made in" label, ultimately driving them to develop a positive or negative connotation in accordance with their perception of that country (Yassin, et al., 2007). Therefore, brands from countries with a favorable image are tend to carry a positive association and are more readily accepted.

Historically, products emerging from less developed or developing countries perceived less favorably among consumers, as they considered being of inferior quality and untrustworthy. Various factors regarding the country of origin contribute to the establishment of a positive or negative perception among consumers, including its level of economic development, the culture and political climate, and country stereotypes (Wang, 1978).

Good mental image of a country can lead to the popularity of the brand and this popularity will eventually lead to brand loyalty. Country image is certainly important. Because serious challenges faced against effort to build a global brand in country such as Iran, Manufacturers are faced with many problems. Negative propaganda against Iran will certainly is affected image of foreign consumers and banking sanctions against Iranian banks that would be very difficult for the foreign customers to initiate to deal with Iranian manufacturers. High customs duties and regulations of local authorities lead to delay in arrival of raw materials and high costs and more waste of time. The results of all these factors have caused big challenges for manufacturers to make trust in international markets as author. Obviously, the consequences of a favorable image of the country is vital for brands that want to operate in overseas market country of origin on the overall perception of the brand will affect customers. The effects of the less well-known brand are different. Their country of origin has a significant impact on brand image perception that is multi-dimensional. These dimensions are so different in whole country and all different brands. Marketers should consider which dimension is more important to magnify for each brand in specific country (Kaubaa, 2007). Ultimately, the power of a brand lies in the minds of consumers or customer (Keller, 2000). One of the realities of the global marketing is stereotypical attitudes about foreign products. Stereotypical attitudes may be beneficial to the marketing manager or the activities that make it difficult. No country has a reputation for its products exclusively favorable or unfavorable there are very large differences between people's attitudes about foreign products.

\section{BRAND ENGINEERING}

Customers relate quality of a product to its brand. Brand can transfer positive or negative message to the customer's mind and this depends on advertising and sales promotion programs, and assess the reputation and experience using the product. Several factors cause it to get certain goods in the minds of consumers. One of the factors considered by multinational producer companies in the world is the effect of name of producer country name on costumers mind. Origin 
country effect can be defined as any influence that Manufacturer Company has on a consumer's positive or negative perception of a product (Cateora and Graham, 1999).Consumers tend to be stereotype based on their experiences, beliefs and etc about countries whether if they are industrialized or developed or developing. This is not solely, because that country or that good but it is due to the perception to get in minds, for that high quality product. For Example it is believed that industrial countries have the best quality product. In less developed countries people prefer goods manufactured abroad to domestic goods. Of course, there are exceptions to the generalization of this idea above mentioned but this is true that name of the country affects mentality of the consumers about certain products. , Based on recently studies, whatever there are knowledgeable consumers, there will more Influenced by the manufacturer's name. During the development and marketing strategy, planning multinational companies should pay more attention to effects of the negative attitude towards the product manufacturer's name on the success or failure of products and overcome the possible problem.

\section{BRAND PLAN}

One problem with Asian companies in creating and promoting the construction of commercial signs locally or internationally, Country of origin has an impact on brand image. The Asian country goods made from cheap and low quality images suffer from having but the truth is that the quality of Asian products, according to large businesses, as well as many Western countries. Thus, the reality is that international trade signals offer better quality than the local symptoms. According to research, two important factors that are important for consumers to determine their origin countries include brand awareness and knowledge and observed risk.

In famous brand products, origin country for the consumer would be less important. When products are not from a familiar brand, more consumers are paying attention to its origin country.

The observed risk: Labels containing the words "built" known to have little impact on popular brands. Public awareness on the well-known brand names, regardless of place of manufacture, offer quality, the brand's reputation is secure. Thus, the observed risk can be greatly reduced.

According to historical findings, animal skins, first lining for human, since person has realized that can protect physical body against the risk of predatory wild animals and other external factors. Also the against use of heat and cold and other natural factors, Species has had to deal with the leather According to paleontologists, the use of animal skins to form leather to more than three thousand years ago in ancient Persia returns. However, the ancient Iranian mythological Draftsman leather is still older. About 1500 years before Christ the Iranians have used the skin for clothing. Centuries proudly say that the leather industry is involved in industrial work through the skin, which dealt with the Old World has second career. Hundreds of different products over many years has made of leather. Some of these goods are used in daily life and industry, some devices are easy, some nice and friendly and all are expensive. Indeed, there is concern, natural and has been ever-present that will not hurt anyone (at least to think that someone is not to harm others). Indeed, there is concern. Natural product and Leather goods leather has not been harm to anyone (At least to think that someone is not to harm others).For years he was relieved that all about leather.
Leather and leather products for advertising, but I do not need to be marketing the leather. Environmental problems are from the 70s onwards and gloves, furniture, bags and other things from the plastic industry, leather belt with his problems. Salient activities of animals and livestock are also an advantage because with all these problems should be advertised on the leather. Leather industry, though it is old does not need to advertise.

\section{PROCESS OF PRODUCING LEATHER}

Product of steps 1 and 2 as pickled and wet blue is only purchasing and selling which has more value but employment is low. While stages 3 and 4 as leather crust in addition to buying and selling leather products are directly used in manufacturing value added and employment is very high.

Leather $=$ cuticle + tannery materials + physical and chemical operations.

Crust $=$ half-prepared leather ready for form.

Consumers often refer to origin country for evaluating products, and some authors suggest that favorable perceptions about the country result in the according of favorable attributions to brands from that country .Therefore the perception of a desirable and pleasant country of origin, the consumers decision-making role playing facilitate and expedite the initial assessment of each product. Today the image of the country of original manufacturer is one of the most important elements of international product marketing literature (al-Sulaiti \& ebid 1998). It concluded that the perceived image of the origin country, if the consumer is aware of the brand origin on consumer perceptions of brands is available about its impact (Peterson and Jolibert 1995).

There is strong evidence that origin country can influence buyer's perceptions and as such it is a perceptual construct. They show that beliefs about a product and its country of origin can be descriptive and based on direct recent experience with the product; inferential based on past experience with the product and informational based on external sources of information such as friends/relatives or advertising. Purchasers often have stereotypes about countries in relation to products and services that based on experience, hearsay and myth the idea that countries have a name or picture and are not a new idea. In todays globalize world, a global power company and a strong country needs a strong name and logo. In order attract consumers and investors and to maintain. While the world moves towards globalization. All people have similar hardware and should have similar software to operate with them. Brand of a country can be more important, by establishing a link with foreign investors (Jaffe.D,Nebenzahi 2001,130). In (1996) Mahsouran found that country of origin information on the reaction of foreign products influence Chinese customers. The results of these studies showed the country of origin may be subject to adjustment by other factors such as type of product or the product consumed. He also showed that the perception created by the country of origin on Chinese consumers affect the decision apart from cultural influences. 


\section{ANALYZING EFFECTS OF ORIGIN COUNTRY ON PERCEPTIONS OF INDUSTRIAL PURCHASERS ABOUT PRODUCTS QUALITY}

Interior Designer, Interior assembly - the country producing the parts is the country which tests its effects on several measures of product quality (design, comparison, specifications, and production). Researches in Mexico and America show that all 3 factors effected the perception of purchasers about quality of products. In summary we can say that globalization and becoming more prominent and increasing the communication cause to increase importance of foreign specification between the purchase agencies. Ignoring the origin Country effects in these devices is a big mistake. Consequently, more than any other time, research on effects of origin Country on industrial buyers' behavior needed (2003, 120, GaryszInsch). With the globalization expansion and integration economic among countries, Export is becomes important strategies for international companies and national economies .To compete overseas and domestic markets, Companies must understudied them for use their resources and capabilities and advantages competitive Two ways can organizations can two ways gain competitive advantage with better performance of the company and second, sources of advantage. Resource-based theory, firms can only obtains specific resources to achieve sustainable advantage competitive. Thus, to achieve competitive advantage, high financial performance, companies must seek sources of valuable, rare, unique and irreplaceable. Resource can classified as physical resources, human and organizational. Resources can also as tangible resources, including physical and financial assets Intangible resources to intellectual assets, which include credit information resources as technology, Customer trust, brand, distribution management, organizational culture and management skills will be included. Because of the intense competition exist among the competitors in the global markets, It is more important develop and maintain long-term relationships with customers and close, to facilitate the easier to understand the needs of customers in international markets. In order to compete in international markets, companies must provide more value to their customers. The main objective in maintaining close relationships with customers and their satisfaction is to build loyalty to the company, brand and products. For increasing customers loyalty that companies export, resulting in cost reduction and competitive advantage and has a positive effect on company performance. Loyalties through increased sales, increased customer retention costs reduced. Underlying interference in the affairs of clients and provides the company's activities. Develop and maintain good relations with foreign customers and a strong positive effect on corporate performance makes (Haluk \& Mehmet, 2010).

\section{RELATIONSHIP BETWEEN BRAND EQUITY AND ITS DETERMINING FACTORS WITH EXPORTS}

\subsection{Perceived quality}

It is not the real quality of the product but the customer's perception of the overall quality or superiority of the product (or service) with respect to its intended purpose, relative to alternatives. Perceived quality of the property to be defined "Consumer's judgment about the overall superiority of a product. The internal assessment of product quality by consumers after they are experiencing is not by managers and professional (Zeithaml, 1988). Perceived quality lends value to a brand in several ways: high quality gives consumers a good reason to buy the brand and allows the brand to differentiate itself from its competitors, to charge a premium price, and to have a strong basis for the brand extension (Aaker, 1991). Marketers across all product and service categories have increasingly recognized the importance of perceived quality in brand decisions (Morton, 1994).

\subsection{Brand loyalty}

Oliver brand loyalty be defined "to create a deep to buy or support of a product or service's preferred and a continually recurring in the future and regularly are buying Unlike the situation and the marketing efforts that may Behavior change may cause.

\subsection{Brand performance}

Performance indicators that are described how can the product or service functional needs of your customers will respond well; what is the brand of quality indicator and to what extent can economic needs, functional, aesthetic and other goods or services meet the customer demands it makes as:

- Main elements and features complementary

- Reliability, durability, serviceability and re-use

- Service effectiveness and service effectiveness of service empathy

- Style and product design

- Price

Consumers may have many reasons for the weak brand-tobrand performance to such shortcomings in services or higher costs. Other reasons for management actions (e.g. competitors attracted customers) Or other of them are (for example, customers are out of business, Following the decision managers' company to change suppliers.

\section{METHODOLOGY}

Research framework designed to test the above hypothesized, on the influence of brand equity as perceived quality, brand loyalty and brand performance is on exports for this purpose, and the leather industry in Iran (Tabriz) has targeted the market. Leather Tabriz in Iran is one of the largest exporters of leather .Data and information has gathered by the field method and interviewed.

Background investigation of methods to study library with books and magazines and internet regulated. Tools for data collection, Kevin Keller are used structured questionnaires. Data were collected Leather customer Turkey, is the Azeri and Georgian. For determine reliability of the questionnaire was used alpha Cranbach. The result of 0/874 is that the credit is required. Questionnaire based on Likert technique used. For each scale score between one and five were and the questions adjusted that the assumptions are examined. Then got through statistics relating to the export of leather in 1389 with customs.60 questionnaires were sent with emails about 41 percent of the questionnaires have been answered. Statistical analysis performed. For all questions prove or disprove hypotheses to help SPSS software Kruskal-Wallis test due to low data and to rank them and not follow a normal distribution of data is used. The descriptive data showed in Table 1. 
Table 1. Descriptive data

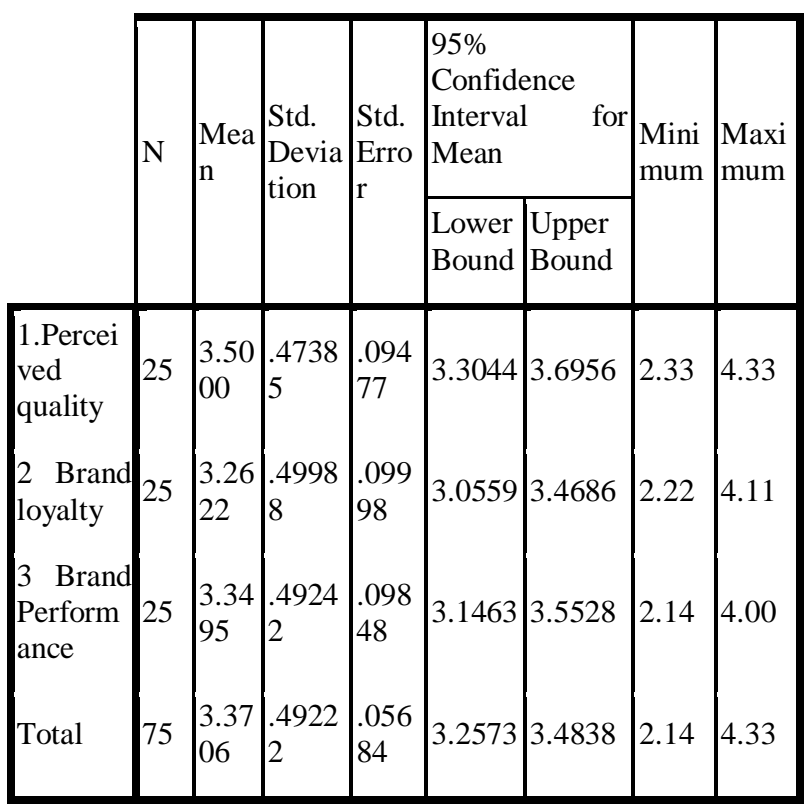

\section{FINDING}

Crustal-Wallis results show that country of origin brand equity and each of its dimensions has no significant effect on exports. country of origin and expect the customers to evaluate product quality, risk and other variables affected of thousands of experiences and information received from customers will be formed. Brand questionnaires shown in Table 2.

Table 2. Brand Questionnaires

\begin{tabular}{|c|c|c|c|}
\hline $\begin{array}{l}\text { Questionnaire to measure } \\
\text { brand perceived quality: }\end{array}$ & $\begin{array}{l}\text { Very } \\
\text { good }\end{array}$ & Good & Average \\
\hline $\begin{array}{l}\text { 1- How much do you think } \\
\text { Iranian leather to be quite } \\
\text { enough to satisfy your needs? }\end{array}$ & 89 & $0 / 947$ & $\begin{array}{l}\text { Perceived quality } \\
\text { effect on export }\end{array}$ \\
\hline $\begin{array}{l}\text { 2- How much is it easy to work } \\
\text { with Iranian leather? }\end{array}$ & 89 & $0 / 426$ & $\begin{array}{l}\text { Perceived quality } \\
\text { effect on export }\end{array}$ \\
\hline $\begin{array}{l}\text { 3-How reliable is the quality of } \\
\text { the Iranian leather?. }\end{array}$ & 89 & $0 / 840$ & $\begin{array}{l}\text { Perceived quality } \\
\text { effect on export }\end{array}$ \\
\hline $\begin{array}{l}\text { 4-How is the package of Iranian } \\
\text { leather? }\end{array}$ & 89 & $0 / 344$ & $\begin{array}{l}\text { Perceived quality } \\
\text { effect on export }\end{array}$ \\
\hline $\begin{array}{l}\text { 5-what is your idea about the } \\
\text { durability and of the brand that } \\
\text { Iranian leather? }\end{array}$ & 89 & $0 / 321$ & $\begin{array}{l}\text { Perceived quality } \\
\text { effect on export }\end{array}$ \\
\hline \multicolumn{4}{|l|}{$\begin{array}{l}\text { Questionnaire to measure } \\
\text { brand loyalty: }\end{array}$} \\
\hline $\begin{array}{l}\text { 6-Do you prefer Iranian leather if } \\
\text { it has the same price with other } \\
\text { brands? }\end{array}$ & 89 & 0/736 & $\begin{array}{l}\text { brand loyalty } \\
\text { effect on export }\end{array}$ \\
\hline $\begin{array}{l}\text { 7-Do you prefer not to buy } \\
\text { another brand and wait for your } \\
\text { own favorite brand if Iranian } \\
\text { leather is not available at the } \\
\text { market? }\end{array}$ & 89 & $0 / 241$ & $\begin{array}{l}\text { brand loyalty } \\
\text { effect on export }\end{array}$ \\
\hline
\end{tabular}

\begin{tabular}{|c|c|c|c|}
\hline $\begin{array}{l}\text { 8- Is Iranian leather your first } \\
\text { choice to buy }\end{array}$ & 89 & $0 / 8$ & $\begin{array}{l}\text { brand loyalty } \\
\text { effect on export }\end{array}$ \\
\hline $\begin{array}{l}\text { 9- How much is Iranian leather } \\
\text { unique? }\end{array}$ & 89 & $0 / 826$ & $\begin{array}{l}\text { brand loyalty } \\
\text { effect on export }\end{array}$ \\
\hline \multicolumn{4}{|l|}{$\begin{array}{l}\text { How much do you agree with } \\
\text { following sentences? }\end{array}$} \\
\hline 10- I am loyal to Iranian leather. & 89 & $0 / 532$ & $\begin{array}{l}\text { brand loyalty } \\
\text { effect on export }\end{array}$ \\
\hline 11-I buy it whenever I can. & 89 & $0 / 427$ & $\begin{array}{l}\text { brand loyalty } \\
\text { effect on export }\end{array}$ \\
\hline $\begin{array}{l}\text { 12-I buy whatever product I can } \\
\text { buy }\end{array}$ & 89 & $0 / 673$ & $\begin{array}{l}\text { brand loyalty } \\
\text { effect on export }\end{array}$ \\
\hline $\begin{array}{l}\text { 13- I feel that Iranian leather is } \\
\text { the only product I needed }\end{array}$ & 89 & $0 / 294$ & $\begin{array}{l}\text { brand loyalty } \\
\text { effect on export }\end{array}$ \\
\hline $\begin{array}{l}\text { 14- This is one of those which } \\
\text { prefer to buy its products or use } \\
\text { it }\end{array}$ & 89 & $0 / 447$ & $\begin{array}{l}\text { brand loyalty } \\
\text { effect on export }\end{array}$ \\
\hline $\begin{array}{l}\text { 15-If Iranian leather is not } \\
\text { available and I do have to buy } \\
\text { another brand, I feel the } \\
\text { difference between them }\end{array}$ & 89 & $0 / 167$ & $\begin{array}{l}\text { brand loyalty } \\
\text { effect on export }\end{array}$ \\
\hline \multicolumn{4}{|l|}{$\begin{array}{l}\text { Questionnaire to measure } \\
\text { brand performance }\end{array}$} \\
\hline $\begin{array}{l}\text { 16-How is the innovative Iranian } \\
\text { leather? }\end{array}$ & 89 & $0 / 698$ & $\begin{array}{c}\text { brand } \\
\text { performance } \\
\text { effect on export }\end{array}$ \\
\hline $\begin{array}{l}\text { 17-Haw much do you think the } \\
\text { manufacturers of Iranian leather } \\
\text { understand your needs? }\end{array}$ & 89 & $0 / 8$ & $\begin{array}{c}\text { brand } \\
\text { performance } \\
\text { effect on export }\end{array}$ \\
\hline $\begin{array}{l}\text { 18-How for do you think } \\
\text { builders of Iranian leather pay } \\
\text { attentions to your ideas? }\end{array}$ & 89 & $0 / 826$ & $\begin{array}{c}\text { brand } \\
\text { performance } \\
\text { effect on export }\end{array}$ \\
\hline $\begin{array}{l}\text { 19- How much admired Iranian } \\
\text { leather? }\end{array}$ & 89 & $0 / 446$ & $\begin{array}{c}\text { brand } \\
\text { performance } \\
\text { effect on export }\end{array}$ \\
\hline $\begin{array}{l}\text { 20- How much do you respect } \\
\text { Iranian leather? }\end{array}$ & 89 & $0 / 793$ & $\begin{array}{c}\text { brand } \\
\text { performance } \\
\text { effect on export }\end{array}$ \\
\hline $\begin{array}{l}\text { 21- How reliable is Iranian } \\
\text { leather? }\end{array}$ & 89 & $0 / 339$ & $\begin{array}{c}\text { brand } \\
\text { performance } \\
\text { effect on export }\end{array}$ \\
\hline
\end{tabular}

Effect country of origin of factors such as consumer early recognition and Mode of information processing and international political and economic sanctions and insurance problems, all the perception of the buyer affected.

Hypothesis 1) Perceived quality has an impact on exports.

$\mathrm{H}_{\mathrm{o}}$ : perceived quality does not affect exports

$\mathrm{H}_{1}$ : perceived quality has an impact on exports

Questions the number of 1 to 6, hypotheses of perceived quality are tested. According to Table Given Crustal-Wallis test statistic values is p-value greater than 0/05. For all 
questions for export in 1389 in terms value of quantity and dollar, perceived quality have no impact on exports, the value P> 0/5 so I accepted $H_{0}$ and will be rejected $H_{1}$. Therefore, all questions in a significant level of $\alpha>0 / 05$ customers perceived quality does not impact on exports

Hypothesis 2) Brand loyalty is the impact on exports.

$\mathrm{H}_{\mathrm{o}}$ : Brand loyalty not impact on the export

$\mathrm{H}_{1}$ : Brand loyalty is impact on the exports

Questions the number of 7 to 15 hypotheses is tested brand loyalty. According to Table Given Kruskal-Wallis test statistic values is $p$-value greater than $0 / 05$ for all questions for export in 2010 in terms value of quantity and dollar, perceived quality have no impact on exports. The value $\mathrm{P}>0 / 5$ so can accept $\mathrm{H}_{\mathrm{o}}$ and will be rejected $\mathrm{H}_{1}$. Therefore, all questions in a significant level of $=\alpha=0 / 05$ does not affect the export of brand loyalty.

Hypothesis 3) Brand Performance is the impact on export

\section{$\mathrm{H}_{\mathrm{o}}$ : Brand Performance not impact on export}

\section{$\mathrm{H}_{1}$ : Brand Performance is impact on export}

Questions 16 to 22 hypotheses are tested Brand Performance. According to Table Given Kruskal-Wallis test statistic values is p-value greater than $0 / 05$ For all questions for export in 2010 in terms value of quantity and dollar, perceived quality have no impact on exports. The value $\mathrm{P}>0 / 5$ so can accept $\mathrm{H}_{\mathrm{o}}$ and will be rejected $\mathrm{H}_{1}$. Therefore, all questions in a significant level of $\alpha=0 / 05$ does not affect the export of Brand Performance.

Research of Bani Abbas F. (2010) has done. American importers do not recognize appropriate financial performance that related to brand financial performance can confirmed. The research that the image of one country as the country has can confirm. The results of this study are one of country images of war and violence. While this country has contributed significantly to global markets. This country technology and medical science has achieved many successes. This country needs people to make informed business environment and relaxation in the country.

How can nation branding help a country's image building if it plagued by war, poverty, crime or terrorism? Without a good product, branding would work to no avail. Branding will not work if other components of the strategy (finance, R\&D, production, distribution) fail to deliver what the customers have wanted. Other factors in the political and economic environment also affect a nation's image, and probably to a greater degree. There are places where branding, no matter how ingenious and creative, simply will not work. A case in the point is North Cyprus (Ahmet, 2003).

However; this is a kind of misunderstanding. The change in the national image of Spain is the result of fundamental changes in its political, economic and social systems taken place in the past 20 odd years, not the result of some wishful campaigns in nation branding. In contrast, Zimbabwe is a country with rich tourist resources but under the tyranny of the current regime, the country is unable to exploit these market opportunities. Before political reform takes place, there is no role for nation branding.

\section{CONCLUSIONS}

It should note that having famous being is a different with brand in international market. Most of our manufacturers are known, but there are lacks its own DNA. Effective functioning of the brand appears to know the customer is willing to pay more money for our product or service.

This additional payment for customer value, credibility and differentiate our brand. Customers in this industry are not willing to pay that extra amount to get the Iranian leather. There are also brand in a competitive market. However, due to having a monopoly in Iran, There is also many complications of customs laws, import of raw materials industry, having a brand and compete in foreign markets is difficult and impossible. The factories are not equipped with the technology world, High customs duties and the bureaucracy against the temporary entry of chemicals required for leather process production, other problems in this industry is to achieve export goals. There are have a lot of problems in the leather industry. There are such problems many obstacles facing export of this product. A lots of problems having which has been in the foundation of the industry, that Brand equity is not considered in this industry and there have not role in this industry .Problems in this industry, power producers to compete in global markets is lower and minimized. The producers cannot promise to act and product quality and standards are production uniformly Able to be competitive in international markets and in such circumstances brand equity cannot be effective on the export of this product. In summary can say, according to the research findings in this population brand equity has no impact on exports To increase the export of basic problems that must first be referred to be considered despite many problems in this industry, brand equity Could not have an impact on exports and every one of the brand factor is also ineffective.

The research results of previous research would violate. Apart from such factors on the export of brand equity directly affects that can neutralize the effect of the brand. Also each operating brand equity, perceived quality, brand performance and brand loyalty, no effect on increasing export. Competitive advantage cannot be effective through long-term prices and prices with other factors, such as the superior product, brand, distribution and other factors to consider.

According to previous research on one of the factors that make exports competitive advantage perceived quality factor of the brand products sold in global markets. However, there are factors such as sanctions, exchange rate fluctuations, the absence of intermediate goods desired by the manufacturer and wait in the customs of the agent itself is less as below proposal:

- It suggested that the additional costs on the manufacturing sector eliminated. Chemicals industry is required to reduce import tariffs.

- Data collection specialized in marketing the country's exports, policy in the consortium and encourages small enterprises Integration in and product groups related to establishing corporations in the export, export management companies and export-oriented cluster and non-governmental export development fund considered

Suggestions for future research are as follows:

- Study about effect of sanctions on brand strength and brand value to organizations that work with international markets.

- Whether they can form a consortium to overcome problems and increase the export value

To get better results and universalize it to all industries, recommended that similar research done in other industries as well. If brand engineering management experience and formal 
education improve the precision of the assessment, then within brand engineering brand dispersion should decrease with experience and education, whereas between brands engineering dispersion expected to increase with these two variables. This distinction, new in the literature formalized and empirically supported by a large sample of data for managerial brand. Economical organization s compete with the quality level of their products and services which cannot manage economical organization s competition, will have problems surviving. In order to be able to do this successfully, the products and services economical organization has to view its brand and its customer relationships from a products and services quality improvement perspective. Economical organization $\mathrm{s}$ are facing fundamental issues such as how to design and implement an effective quality service delivery system, which will help to establish and to retain global market share. Much of the published work on quality focuses on manufactured products and services, but managers are paying more attention to emphasizing quality in services. The reason is the general perception that products and services quality is not good.

\section{REFERENCES}

[1] Aaker, D.A. (1991), Managing Brand Equity, Free Press, NewYork, NY

[2] Ahmet, T. (2003), "Whether the low level of tourism in North Cyprus is down to the ineffective application of contemporary marketing theory", unpublished BA thesis, University of Lincoln

[3] Al-Sulaiti and Baker,1998,150-99

[4] Baker, G., Gibbs, B. Holmstrom (1994), The Wage Policy of a Economical organization , The Quarterly Journal of Economics, 92.

[5] Barkham, R, (1996), The Determinants of small Economical organization Growth, London, Jessica Kingsley.

[6] Baron, R. M. and Kenny, D. A. (1986), The distinction in social research, Journal of Personality and Social Psychology, 51.

[7] Barringer, Bruce R And Bluedorn, Allen C.(1999), The Relationship Between Corporate Economical organization al project And Strategic Management, Strategic Management Journal, Strat. Mgmt. J., 20: , 421-444.

[8] Bauer, T.K. and J.P. Haisken-DeNew (2001), Employer Commitment, Labour Economics, 8.

[9] Cateora, P.R. and Graham, J.L. 1999., International Marketing, 10th. Edition,

[10] Fan,y (2006)BRANDING THE NATION: WHAT IS BEING BRANDED? Journal of Vacation Marketing,) 12:1, 5-14.

[11] Farber, H.S. and R. Gibbons (1996), Commitment and Wage Dynamics, The Quarterly Journal of Economics, 111.

[12] Feghhi Farahmand, Nasser (2001), Executive Management Process, Islamic Azad University, Tabriz Branch, Iran, pp 109-203.

[13] Feghhi Farahmand, Nasser (2003), Permanent Management of Economical organization , First edition, Frouzesh Publication, Tabriz, Iran, pp 70-83.
[14] Feghhi Farahmand, Nasser (2003), Strategic Structure of Economical organization Management Process, Forth edition, Islamic Azad University, Tabriz Branch, Iran, pp 110-125.

[15] Feghhi Farahmand, Nasser (2005), Strategic Management of Economical organization, First edition, Frouzesh Publication, Tabriz, Iran, pp 19.

[16] Feghhi Farahmand, Nasser (2009), Economical organization Strategic Plan compilation, First edition, Frouzesh Publication, Tabriz, Iran, pp 74-314.

[17] Feghhi farahmand, Nasser (2011), Active and Dynamic Management of Economical organization , Second edition, Frouzesh Publication, Tabriz, Iran, pp 87-190.

[18] Feghhi Farahmand, Nasser (2011a), Technology Management of Economical organization , Second edition, Frouzesh Publication, Tabriz, Iran, pp 11-198.

[19] FIB (1998). Uusinta tietoa suomalaisten asenteista biotekniikkaan, FIB, Suomen Bioteollisuus.

[20] Finkelstein, S. (1992), Power in top management teams, measurement and validation, Academy of Management Journal, 35 .

[21] Foster, A.D. and M.R. Rosenzweig (1993), Information Commitment, and Wage Rates in Low-Income, The Journal of Human Resources, 28.

[22] Frewer, L.,Rowe, G.,Marsh, R. and Reynolds, C. (2001). Public Participation Methods: Evolving and Operationalising an Evaluation Framework. UK Department of Health.

[23] Gary s.Insch(2003)"'The Impact of country of origin effects on industrial buyer's perceptions of product quality" Management International Review,43,16

[24] Haluk Ko ksal Mehmet 2010, The export competitive advantages of Turkish manufacturing companies, Emerald Group Publishing Limited, Marketing Intelligence \& Planning, Vol. 28 No. 2, pp. 206-222

[25] Irwin McGraw-Hill

[26] Jaffe , E . D . and Nebenzahl , I . D . ( 2001 ) National Image and Competitive Advantage: The Theory and Practice ofCountry of Origin Effect , Copenhagen Business School Press, Copenhagen, 130

[27] Keller, K.L. (2002), Strategic Brand Management: Building,Measuring, and Management Brand Equity, 2nd ed., PearsonEducation, Upper Saddle River, NJ.

[28] Maheswaran,D,1994, Country of Origin Effects: Consumer Perceptions of Japan in South East Asia

[29] Morton, J. (1994), "Predicating brand preference", Marketing Management, Vol. 2 No. 4, pp. 32-44.

[30] Oliver, R.L. (1997), Satisfaction: A Behavioral Perspective on the Consumer, McGraw-Hill, New York, NY.

[31] Paswan and Sharma,2004Brand-country of origin (COO) knowledge and $\mathrm{COO}$ image: investigation in an emerging franchise market Emerald Group Publishing Limited144-55 
[32] Peterson, R.A. and Jolibert, A.J.P. (1995) A metaanalysis of country of origin effects. Journal of International Business Studies 26 (4): 883-900

[33] research. Journal of Economic Psychology, Vol. 20: 521546

[34] Verlegh, P. W. J. \& Steenkamp, J-B. E. M. (1999). A review and meta-analysis of country-of-origin

[35] Wang, C. (1978). The effect of foreign economic, political, and cultural environment on consumers' willingness to buy foreign products. Ph.D. dissertation, Texas A\&M University

[36] www.globes.co.il One country's marketing challenge
[37] Yamen Kaubaa(2007),"country of origin, brand image , perception and brand image structure" Asia pacific journal of marketing, $(20,2$

[38] Yassin, N., Noor, M. \& Mohamad, O. (2007). Does image of country-of-origin matter to brand equity? Journal of Product and Brand Management, Vol. 16 (1): $38-48$

[39] Zeithaml, V.A. (1988), "Consumer perceptions of price,quality, and value: a means-end model and synthesis of evidence", Journal of Marketing, Vol. 52 No. 2, pp. 2-22. 